\title{
Risks Associated of the Waters from Hydric Systems Urban's The case of the rio Barigui, south of Brazil
}

\author{
PAULO ROBERTO BAIRROS DA SILVA ${ }^{1}$, CLEYTON NASCIMENTO MAKARA², ANA PAULA MUNARO ${ }^{3}$, \\ DANIELLE CAROLINE SCHNITZLER ${ }^{3}$, DANIEL CONSTANTIN DIACONU4*, ION SANDU5,6*, CRISTIANO POLETO ${ }^{6}$ \\ ${ }^{1}$ University of Sao Paulo and Federal University of Santa Maria, Linha 7 de Setembro, Frederico Westphalen, 98400-000, Brasil, \\ 2 University of Sao Paulo, Sao Carlos 310, Sao Paulo, 13565-905, Brasil, \\ ${ }^{3}$ Federal Technological University of Parana, Av. Desembargador Westphalen, 637, 80010-110, Curitiba, Brasil, \\ ${ }^{4}$ University of Bucharest, 1 Nicolae Balcescu Av., 010041, Bucharest, Romania \\ ${ }^{5}$ Alexandru Ioan Cuza University of lasi, ARHEOINVEST Interdisciplinary Platform, 22 Carol I Blvd., 700506 Iasi, Romania \\ ${ }^{6}$ Romanian Inventors Forum, 3 Sf. Petru Movila Str., 700089, Iasi, Romania \\ ${ }^{7}$ Federal University of Rio Grande do Sul, Av. Bento Gonçalves, 9500, Porto Alegre, Brasil
}

\begin{abstract}
The quantification of a chemical species isolated in natural waters does not allow the characterization of it as an environmental stressor. Therefore, it is necessary to associate different lines of research that allows the evaluation of risk on the water system. In this perspective, this study carries out approaches based on distinct research lines, allowing physical and chemical quantification in situ, determination of nutrient concentrations, chlorophyll- $\alpha$, total alkalinity and metallic species ( $\mathrm{Cu}, \mathrm{Ni}, \mathrm{Fe}, \mathrm{Cr}, \mathrm{Zn}$ and $\mathrm{Pb}$ ). In addition, the dissolved organic matter was evaluated by means of spectrophotometric techniques and testing of acute toxicity with the organism Artemia sp. and Daphnia magna in water samples from the Barigüi River, southern Brazil. The results point to the existence of degradation processes and the input of organic matter that are affecting the dynamics of the species, influencing their chemical availability and toxicity in the water system.
\end{abstract}

Keywords: Urban water systems, metal species, nutrients, effluent supply, risk assessment

Due to their ability to dissolve and entrain compounds, natural waters attach to geological characteristics and are influenced by the type of human activity in the river basin [1-11]. Among the components that contribute to water systems, the following stand out: particulate matter, nutrients, organic matter and metal species $[12,13]$.

In urban water systems, the concentrations of metallic species, nutrients and organic matter are, in general, several times higher than levels found in other stretches of a nonurbanized river, and may express significant damages to the ecosystem [14-19]. Metallic species differ from organic pollutants because they are not degradable and may accumulate in organisms and environmental compartments influencing their toxicity [20-28].

The chemical availability of metallic species in natural waters is not only related to their abundance, depending on a complex combination of factors, such as: solubility, affinity for suspended solids and susceptibility to complexation processes in organic compounds [29,30]. Other compounds, when present in higher concentrations, in relation to the background may cause deleterious effects on the environment, such is the case of nutrients such as phosphorus and nitrogen and organic matter that may lead to eutrophication processes in the water system [19, 30, 31].

These chemical species are important in the functioning of aquatic systems, but can also act as environmental stressors [32]. The term 'environmental stressor' is used herein to describe any chemical species that may induce adverse effects on individuals, populations, communities or ecosystems [33]. The risk assessment associated with the presence of these chemical species can be understood as a process that characterizes the likelihood of adverse ecological effects that may occur or that are occurring in a medium as a result of exposure to one or more stressors [34-40].
The toxic potential of chemical agents of different characteristics in complex mixtures such as urban waters can be better evaluated through the association of acute environmental toxicological tests with representative species [41]. The evaluation of the toxicity of chemical species to different reference organisms makes it possible to evaluate the momentary environmental condition of the water bodies [42, 43].

Thus different lines of research should be employed in the study of natural waters to evaluate their environmental quality [44]. This perspective of integration is expressed by Resolution 357 of 2005 [45] that establish quality standards for different chemical species.

Thus, this study focuses on the potential risk associated with the urban waters of the Barigüi River, Curitiba metropolitan region, South of Brazil. The following experiments were carried out: (i) physical-chemical characteristics in situ, using a multiparameter device (Hydrogenation - $\mathrm{pH}$, redox potential - Eh, dissolved oxygen - OD, turbidity - UNF, total dissolved solids - TDS, electrical conductivity-EC, resistivity- $\Omega$ ); (ii) in the determination of ammonia concentration by electrode ion selective method 4500N [46]; (iii) ortho-phosphate method 4500PC [46]; (iv) total phosphorus by the 4500P method [46]; (v) chlorophyll-á by the method L5.306 [47]; (vi) determination of total alkalinity using the 2310B method [46]; (vii) characterization of the organic matter dissolved by Molecular Absorption Spectroscopy in the UV-Vis region and Molecular Fluorescence Spectroscopy; (viii) in the quantification of the average concentrations of metallic species via protocol 200.2 [33] by Atomic Absorption Spectrometry with Flame Atomizer (FAAS) and (ix) performing acute toxicity tests with the microcracks Arthemia sp. According to N-2588 and Daphnia magna [42].

*email: diaconudc@hotmail.com; ion.sandu@uaic.ro 


\section{Experimental part}

\section{Material and methods}

Study area

Located in the metropolitan region of the city of Curitiba, southern Brazil, the Barigüi River has an extension of 66 $\mathrm{km}$ [48]. The occupation of the region upstream of the river, in the municipality of Almirante Tamandare $\left(25^{\circ}\right.$ $22^{\prime} 49.5^{\prime \prime} \mathrm{S}$ and $49^{\circ} 18^{\prime} 03.7^{\prime \prime} \mathrm{W}$ ), is predominantly rural but small dispersed urban centers occur.

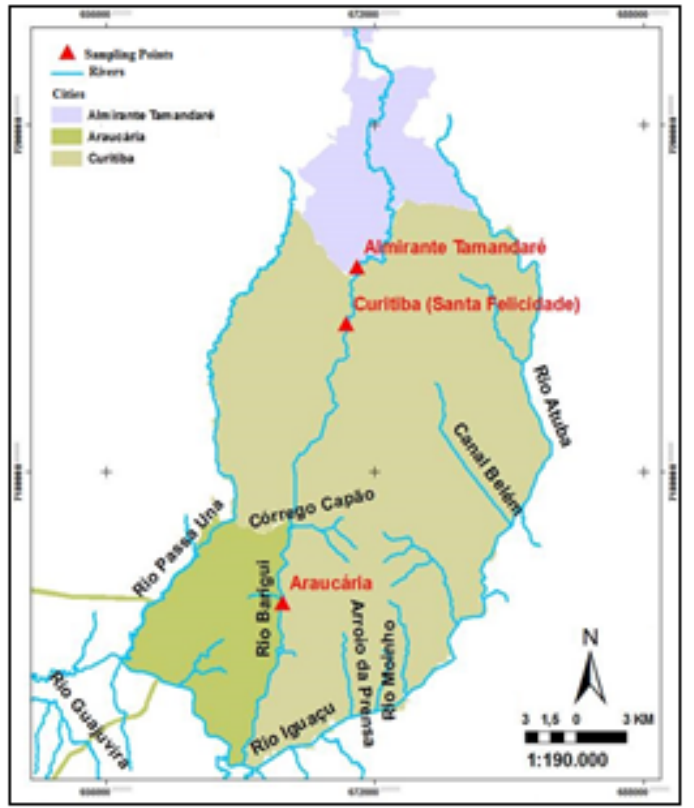

Fig. 1. Location of the Sampling Points and Limits of the Barigui River Study Area

In the middle portion of the river, in the municipality of Curitiba, is located the district of Santa Felicidade $\left(25^{\circ}\right.$ $24^{\prime} 37.4^{\prime \prime} \mathrm{S}$ and $49^{\circ} 18^{\prime} 24.7^{\prime \prime} \mathrm{W}$ ), a region of high urban occupation, with several commercial and service establishments. The downstream region, in the municipality of Araucaria ( $25^{\circ} 33^{\prime} 20.56$ "S and $49^{\circ} 20^{\prime} 32.70^{\prime \prime} \mathrm{W}$ ), has industrial dominance, in it is located the Industrial City of Curitiba, part of the Industrial City of Araucaria and one of Petrobras' oil refineries [49, 50].

These industrial zones have attracted a number of regular and irregular urban occupations, small metallurgists and service providers that add complexity to the area [4951].

Sampling, preservation, reagents and solution preparing

The water samplings followed clean technique protocols [52] and were carried out in two sampling campaigns in the year 2014. All the collection and storage containers went through preparation processes in systems of detergent baths $10 \%$ by $24 \mathrm{~h}$, three washes with distilled water, followed by a $10 \%$ nitric acid bath for 24 hours, with five washes with ultrapure water and drying at room temperature [53].

The procedures for collecting water were always performed by two people (dirty hands approach to clean ones), where one is responsible for the handling of materials that come in direct contact with the samples and the other handles the materials destined to receive the sample [54].

The samples of water intended for analysis of metallic species, nutrients, chlorophyll- $\alpha$, total alkalinity and acute environmental toxicological tests were collected with polypropylene buckets and stored in large mouth bottles with a lid of $1 \mathrm{~L}$ polypropylene, both acclimatized with water from the environment. The samples were deposited in polypropylene bags of $3 \mathrm{~L}$, double closed with ties, identified with internal and external tags and stored in icebox until the arrival at the laboratory [53, 55]. The samples destined to the characterization of organic matter were the same, differentiating from the one collected in stainless steel bucket and storage in amber bottles with lids, of $1 \mathrm{~L}$.

All the chemical reagents used in the study had analytical grade and the solutions were prepared with ultrapure water from the Milipore Direct-K 8UV apparatus using clean glassware in bathing systems. Samples were handled on granite countertops, previously cleaned and covered with paper towel, with spatulas and disposable polythene gloves with no powder. Materials such as filtration membranes (cellulose acetate and/or glass fiber) were handled with the aid of plastic tweezers.

\section{Parameters in situ}

During the sampling campaigns physical and chemical parameters were quantified in situ with the Hanna HI 9829 multiparameter equipment, namely: Dissolved Oxygen, Temperature, Resistivity, Conductivity, Dissolved Solids Content and Redox Potential. The electrodes HI 76098292 (DO), HI 7609829-1 (PH/ORP), HI 7609829-4 (EC/ Turbidity) brand Hanna were used, calibrated with standard solutions recommended by the manufacturer.

\section{Determination of ammonia in water samples}

The concentrations of ammonia established via $4500 \mathrm{~N}$ protocol [46] were obtained from aliquots of $25 \mathrm{~mL}$ of water from the environmental samples. The analytical curves were built from standard ammonia solution (4001-03 Hanna) at concentrations of $0.10 ; 0.20 ; 0.50 ; 2.00$ and 4.00 $\mathrm{mg} \mathrm{L}^{-1}$. The obtained equation of the straight line and correlation coefficient were $\left(y=-26.6 \ln X-64.4 ; R^{2}=0.99\right)$.

\section{Determination of phosphorus in water samples}

The quantification of the orthophosphate fractions $\left(\mathrm{P}_{\mathrm{O}}\right)$ was carried out by the ascorbic acid method, according to 4500 PC protocol [46]. The quantification of total phosphorus $\left(\mathrm{P}_{\mathrm{To}}\right)$ followed the methodology of acid digestion and heating for conversions of all forms of phosphorus in orthophosphate, according to protocol 4500 $P$ [46].

The analytical curve was carried out by diluting a standard phosphate solution ( $50 \mathrm{mgP}^{\mathrm{L}} \mathrm{L}^{-1}$ ). Samples were prepared in triplicate with addition of $10 \mathrm{~mL}$ of the sample in test tubes and the quantification was carried out in a Varian spectrophotometer (model Cary 50) at wavelength of $890 \mathrm{~nm}$, the absorbance being directly proportional to the concentration of phosphorus.

The analytical curve was prepared for ortho-phosphate at concentrations: $0.1 ; 0.2,0.3 ; 0.5$ and $0.9 \mathrm{mg} \mathrm{L}^{-1}$ and presented the following equation of line and correlation coefficient: $y=625.42 x-0.01\left(R^{2}=0.99\right)$. For Total phosphorus quantification, the analytical curve was prepared at concentrations of $0.1 ; 0.2,0.3 ; 0.5$ and $0.9 \mathrm{mg}$ $L^{-1}$ and presented the following line equation and correlation coefficient $y=605.9 x-0.02\left(R^{2}=0.99\right)$.

\section{Determination of chlorophyll- $\underline{\alpha}$ in water}

Chlorophyll- $\alpha$ was determined by spectrophotometric method according to protocol $L 5.306[47,56]$. The readings were obtained in a Varian brand molecular absorption spectrometer (model Cary 50) in quartz cuvette, with optical path of $1 \mathrm{~cm}$.

\section{Determination of the Trophic State Index}

The Trophic State Index (TSI) assesses water quality for nutrient enrichment and its effect related to excessive 
algae growth [47]. The following equations allow us to calculate the Trophic State Index (TSI), where they classify the environments according to their trophic degree:

$$
\begin{aligned}
& T S I(C C)=10 x\left(6-\left(\left(-0,7-0,6 x\left(\frac{\ln \llbracket C C)}{\ln \llbracket 2)}\right)-20\right) \rrbracket \rrbracket\right.\right. \\
& T S I(T P)=10 x(6-((0,42-0,36 x(\ln \llbracket T P)) / \ln \llbracket 2))-20) \rrbracket \rrbracket
\end{aligned}
$$

TSI will be the simple arithmetic mean of the indexes relating to total phosphorus and chlorophyll- $\alpha$, according to the equation:

$$
T S I=\frac{[T S I(T P)+T S I(C C)]}{2}
$$

where:

TP is the total phosphorus concentration

$\mathrm{CC}$ is the concentration of chlorophyll- $\alpha$, both in $\left(\mu \mathrm{g} \mathrm{L}^{-1}\right)$.

\section{Determination of total alkalinity in water samples}

The total alkalinity of the samples was carried out in triplicate by the titulometric method according to protocol 2310B [46], where the water sample $(100 \mathrm{~mL})$ is titrated with hydrochloric acid solution.

\section{Characterization of organic matter in water samples}

To characterize the organic matter, the samples were filtered on a cellulose acetate fiber membrane $(0.45 \mu \mathrm{m})$ and sent to a quartz cuvette, with a $1 \mathrm{~cm}$ optical path, generating molecular fluorescence spectra in the Varian model Cary equipment Eclypse 50. The scan comprises the range of 200 to $800 \mathrm{~nm}$ wavelength.

Molecular fluorescence scanning on emission modality was performed at 200 to $800 \mathrm{~nm}$, with excitation wavelength of $315 \mathrm{~nm}, 5 \mathrm{~nm}$ slit. The synchronized modality was performed from 200 to $800 \mathrm{~nm}$ with $\Delta \lambda=$ $18 \mathrm{~nm}$.

\section{Determination of metallic species in water}

The analysis of the metallic species for $\mathrm{Cu}, \mathrm{Cr}, \mathrm{Pb}, \mathrm{Zn}$, $\mathrm{Fe}, \mathrm{Ni}$ elements was performed using the Atomic
Absorption Spectrophotometer (FAAS) brand GBC (Avanta model) via protocol 200.2 [57]. All the analysis was performed in quintuplicates and to determine the quality of the analytical process, the figures of merit that were determined: Limit of Method Determination (LDM), Precision and Accuracy $[58,59]$.

Acute environmental toxicological tests

The acute toxicity tests were carried out with the microcrack Artemia sp., grown according to methodology 821 R02-12 [60]. The assay consists of the exposure of nauplii (phase I and phase II) to different concentrations of the sample, for 24/48 hours, and real estate counting $[61,62]$.

Another acute toxicity test was carried out with the micro-crustacean Daphnia magma, considered ideal for freshwater due to its sensitivity [63]. The essay consists in exposing young individuals (up to 26 hours of life) for a period of 24 to $48 \mathrm{~h}$ at various dilutions of a sample, with subsequent evaluation of the effecton the swimming ability of organisms [64].

The results expressed by the initial effective concentration that causes effect in $50 \%$ of organisms (EC50), determined by statistical methods. The sensitivity of organisms is tested through periodic testing of reference substances and the use of control charts [64].

\section{Results and discussions}

\section{Parameters in situ}

The results of average concentrations of the physical and chemical parameters are presented in table 1 . In it, one can notice different behaviors for the redox potential, having a reducing character in $(A)$ and oxidant for the other points, which influences the behavior of partition of the species, because in oxidizing environments corrosive processes are facilitated [65].

One can also observe a higher influence of dissolved solids and higher turbidity values in $(A)$, which may be associated to a higher input of particulates in the region,

\begin{tabular}{|l|c|c|c|}
\hline Parameters of the First Campaign & A & SF & AT \\
\hline DISSOLVED OXYGEN (ppm) & $<\mathrm{DL}^{*}$ & 7,7 & 4.9 \\
\hline CONDUCTIVITY $(\mu \mathrm{S} / \mathrm{cm})$ & 582 & 337 & 363 \\
\hline RESISTIVITY $(\mu \Omega \mathrm{cm})$ & 0.002 & 0.003 & 0.003 \\
\hline DISSOLVED SOLIDS $(\mathrm{ppm})$ & 294 & 169 & 183 \\
\hline SALINITY $(\mathrm{PSU})$ & 0.3 & 0.2 & 0.2 \\
\hline TURBIDITY $(\mathrm{UNF})$ & 52.8 & 11.7 & 14.4 \\
\hline TEMPERATURE $\left({ }^{\circ} \mathrm{C}\right)$ & 18.7 & 16.9 & 16.6 \\
\hline PRESSURE $(\mathrm{psi})$ & 13.4 & 13.4 & 13.3 \\
\hline REDOX POTENTIAL $(\mathrm{mV})$ & -18.8 & 53 & 48 \\
\hline pH & 7.2 & 6.4 & 6.2 \\
\hline Parameters of the Second Campaign & A & SF & AT \\
\hline DISSOLVED OXYGEN (ppm) & 0.8 & 5.5 & 5.2 \\
\hline CONDUCTIVITY $(\mu S / \mathrm{cm})$ & 274 & 186 & 363 \\
\hline RESISTIVITY $(\mu \Omega \mathrm{cm})$ & 0.025 & 0.035 & 0.003 \\
\hline DISSOLVED SOLIDS $(\mathrm{ppm})$ & 226 & 140 & 162 \\
\hline SALINITY $(\mathrm{PSU})$ & 0.5 & 0.3 & 0.2 \\
\hline TURBIDITY $(\mathrm{UNF})$ & 38.4 & 7.8 & 12.4 \\
\hline TEMPERATURE $\left({ }^{\circ} \mathrm{C}\right)$ & 18.9 & 18.6 & 19.2 \\
\hline PRESSURE $(\mathrm{psi})$ & 13.5 & 13.4 & 13.3 \\
\hline REDOX POTENTIAL $(\mathrm{mV})$ & -128.0 & -35.0 & 27 \\
\hline pH & 6.8 & 8.0 & 6.4 \\
\hline
\end{tabular}

Table 1

PHYSICAL AND CHEMICAL PARAMETERS OBTAINED IN SITU 
since water turbidity is related to the attenuation of intensity that a light beam suffers when crossing it due to the presence of suspended solids [66]. Also in (A) it is noticed that the concentrations of dissolved oxygen are inexpressive (smaller than the limit sensitivity of the sensor HI 7609820-OD, brand Hanna, that is of $0.01 \mathrm{ppm}$ ), characteristic of reducing atmospheres, representing an anaerobic environment favorable to the presence of species such as: sulfides, nitrates and other reduced species, such as manganese II and iron II [67].

The more intense electrical conductivity in (A) expresses the greater presence of ions dissolved in relation to the other points, whose input may be related to anthropogenic actions. The hydrogenion potential $(\mathrm{pH})$ differs in the three regions and values vary around $\mathrm{pH}=7$ and tend to influence reaction and oxidation reactions in chemical species.

Goncalves [47] found $\mathrm{pH}$ values ranging from 5.8 to 7.5 ; Dissolved oxygen ranging from 0.4 to $5.6 \mathrm{mg} \mathrm{L}^{-1}$; the conductivity of 285 to $590 \mathrm{mS} / \mathrm{cm}$ and the turbidity of 7 to $32 \mathrm{FNU}$ for the same environments of the Barigui River. Resolution 357 of 2005 [24] presents as references and dissolved oxygen $4 \mathrm{mg} \mathrm{L}^{-1}$ for rivers of class III. In this sense, (A) presents values of dissolved oxygen lower than those legally required.

The multivariate canonical correspondence analysis (CCA) carried out in the free software PAST version 3.18 verified the influence of the physical and chemical data obtained with the multiparameter equipment in relation to the different sampling points in the Barigui river. In this study the data were nomadic by the function: $(\log X)+1$.

Since $x$ is the physical and chemical variable taken in situ. The CCA focuses on the generation of a unimodal axis in relation to the variable responses, whose results allow the interpretation of characteristics linked to environmental quality (fig. 2).

The canonical correspondence analysis showed higher correspondences between the sampling points of Santa Felicidade (SF) and Almirante Tamandare (AT) in relation to the physical and chemical parameters Dissolved Oxygen, $\mathrm{pH}$ and Eh.
Determination of total alkalinity, nutrients and chlorophylla in water samples

The determination of total alkalinity, ammonia, orthophosphate, total phosphorus and chlorophyll- $\alpha$ in the water column were carried out in triplicate (table 2). In this study, one can see the highest acid buffering capacity in the Araucaria system ( $A$ ) evidenced by the most significant presence of carbonates quantified by total alkalinity. This value may be associated to organic matter decomposition processes, the lower rate of respiration of microorganisms with release and dissolution of $\mathrm{CO}_{2}$ in water $[67,68]$.

The average concentration of ammonia at sample point (A) is higher than that established by the CONAMA [44] resolution 357 of 2005 (5.1 $\left.\mathrm{mg} \mathrm{L}^{-1}\right)$. It is possible to emphasize the less expressive value in (SF) and (AT). This result may represent the contribution of organic matter due to effluent discards in (A).

The Barigui River, Carvalho et al. [69] (2013) presented total alkalinity values ranging from 156.8 to $212.8 \mathrm{mg} \mathrm{x} \mathrm{L}^{-1}$ $\mathrm{CaCO}_{3}$. In the study by Scheffer [70] found $133 \mathrm{mg} \mathrm{x} \mathrm{L}^{-1}$ $\mathrm{CaCO}_{3}$ for the same environment. It should be noted that Fritzsons [71] states that the alkalinity in most Brazilian rivers is between 30 and $500 \mathrm{mg}^{2} \mathrm{~L}^{-1} \mathrm{CaCO}_{3}$.

Schnitzler (2008) found $10 \mathrm{mg} \mathrm{x} \mathrm{L}^{-1}$ of ammonia and Carvalho et al. [69] found average concentrations of orthophosphate varying between 0.052 and $0.074 \mathrm{mg} x$ $\mathrm{L}^{-1}$ in samples of waters from the Barigui River. In alkaline conditions, the predominance of ammonia in free forms is more deleterious to aquatic organisms. In addition, the ammonium ion in hypoxic conditions can be seen as an indicator of the effluent input to the water system $[29,72]$.

The average concentration of orthophosphate is distinct at the sample points, with the most expressive results in (SF)and (AT). However, when evaluating the concentrations of total phosphorus, a reversal of the condition is observed, that is, the average concentrations are more expressive in $(A)$. The average concentrations of total phosphorus for sample points (A) and (SF) were higher than $0.15 \mathrm{mg} \mathrm{L}^{-1}$, a value established in resolution 357 of 2005 [45].

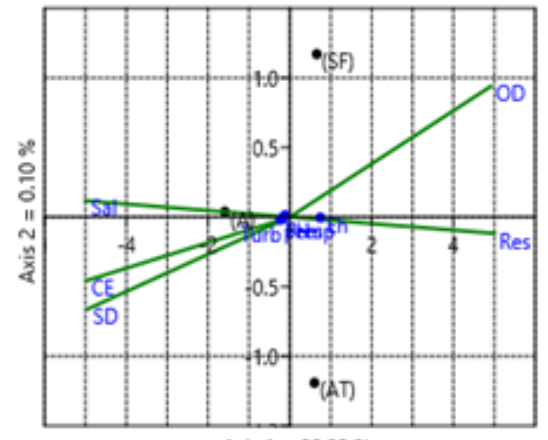

Axis $1=99.89 \%$

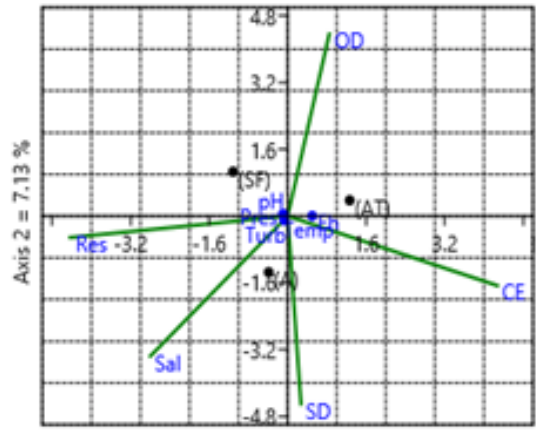

Axis $1=92.86 \%$
Fig. 2. Analysis of canonical correspondence (cca) of the physical and chemical parameters obtained in the sampling points of the Barigui river in the first (right) and the second (left) sampling campaign

\begin{tabular}{|c|c|c|c|c|c|c|}
\hline \multirow[t]{2}{*}{ Parameters } & \multicolumn{2}{|c|}{$\mathbf{A}$} & \multicolumn{2}{|c|}{ SF } & \multicolumn{2}{|c|}{ AT } \\
\hline & Average & C.V. $(\%)$ & Average & C.V. $(\%)$ & Average & C.V. $(\%)$ \\
\hline Total Alkalinity (mg L-1) & 107.8 & 0.9 & 76.2 & 0.8 & 82 & 1.1 \\
\hline Ammonia (mg L $\left.{ }^{-1}\right)$ & 8.3 & 17.4 & 0.05 & 16.5 & 0.02 & 14.1 \\
\hline Orthophosphate (mg L-1) & 0.05 & 2.9 & 0.09 & 2.4 & 0.08 & 1.1 \\
\hline Total Phosphorus (mg L-1) & 0.6 & 2.7 & 0.2 & 3.1 & 0.1 & 2.7 \\
\hline Chlorophyll-a $\left(\mu \mathrm{g} \mathrm{L}^{-1}\right)$ & 3.5 & 13.6 & 0.59 & 9.8 & 3.6 & 14.4 \\
\hline
\end{tabular}

Table 2

TOTAL ALKALINITY, AMMONIA, ORTHOPHOSPHATE 
This result indicates that the presence of phosphorus, mostly bound to organic fractions and due to the presence of domestic and industrial effluents. Chlorophyll- $\alpha$ concentration indicate predominance of algal growth in regions (A) and (AT). However, in general, they are well below the $60 \mu \mathrm{L}^{-1}$ limit established by Resolution 357 of 2005 [45].

\section{Trophic state index}

The result obtained allows the environments to be classified in mesotrophic (SF), eutrophic (AT) and Supertrophic in (A), demonstrating unnatural nutrientinputs to the water system (fig. 3).

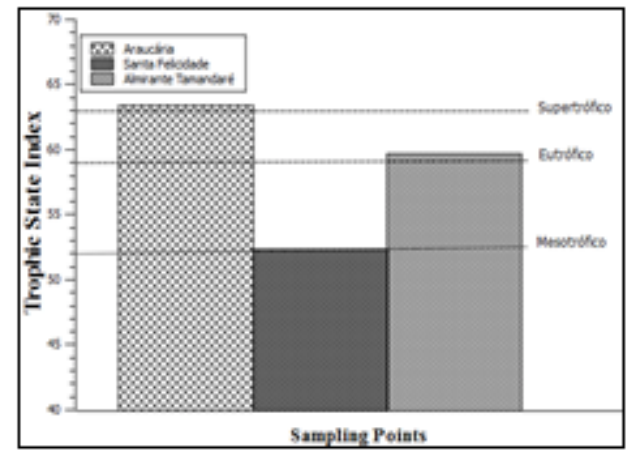

Fig. 3. Trophic state index (tsi) for the Barigui river sampling points, in (A), (SF) and (AT)

The trophic classification of these environments through the EIT suggests a strong anthropic influence on the input of nutrient chemical species, which reflects in terms of biological responses on primary productivity and that can trigger eutrophic processes mainly on the sample point of Araucaria (A).

\section{Characterization of dissolved organic matter}

The spectra presented distinct bands with reduced absorptivity with increasing wavelength. The ratio of absorbances at different wavelengths can characterize the organic matter (table 3 ).

The E250/E365 ratio (250/365 nm) is inversely proportional to the molecular size at the ratio E300/E400 $(300 / 400 \mathrm{~nm})$ indicates the degree of humification and the ratio E465/E665 (465/665 nm), is characteristic of different fractions of organic matter or humic substances obtained from different sources [73-75].

The results point to a reduction of the absorptivity with increasing wavelength, where the intensity of absorption varies for the three regions, being more expressive in $(A)$ $>(A T)>(S F)$ and defined by the absorbance ratio A250/ A203. With the absorbances ratios it can be inferred: (i) that organic compounds in Araucaria (A) can be related to shorter formation chains (E250/E365); (ii) The relation (E300/E400) is associated to the predominance of fulvic humic substances, which have greater facility for metal species complexation; (iii) The relation (E465/E665) shows that the dissolved organic matter in the Araucaria region (A) can be differentiated from the others.

The molecular fluorescence technique (emission modality) was used to characterize the organic matter dissolved in the samples of the Barigüi River. The spectrum scanning was performed in the range between 200 and
$700 \mathrm{~nm}$ with fixed wavelength at $330 \mathrm{~nm}$, considered the point of greatest absorption [76, 77] (fig. 4).

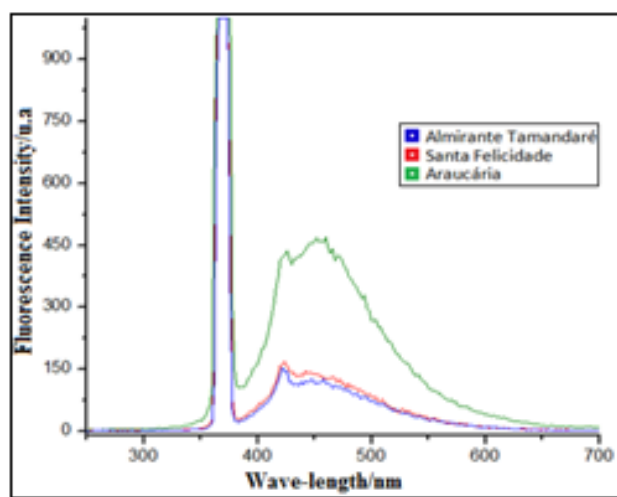

Fig. 4. Molecular fluorescence emission spectrum

Note that the emission spectra were very similar, indicating the similarity of the organic matter in the study regions. The high intensity of fluorescence at $375 \mathrm{~nm}$ is due to the resonance effect resulting from the incident radiation, differences are observed in the maximum intensities in the regions of 425 and $475 \mathrm{~nm}$ for (SF), (AT) and $(A)$ that cannot be associated with expressive concentrations of dissolved organic matter without the association of dissolved organic carbon concentrations.

The molecular fluorescence technique (synchronized modality) was applied in the characterization of organic matter dissolved in water. The excitation and emission wavelengths are simultaneously monitored with a constant interval between them, where

$$
\Delta \lambda=\lambda \text { emission }-\lambda \text { excitation. }
$$

Thus the scanning occurred between 250 and $700 \mathrm{~nm}$ with $\Delta \lambda=18 \mathrm{~nm}$. In figure 5, molecular fluorescence spectra can be observed, these are similar for the samples, at the $275 \mathrm{~nm}, 325 \mathrm{~nm}$ and $400 \mathrm{~nm}$ bands were the most pronounced.

The fluorescence intensities in synchronized mode at $275 \mathrm{~nm}$ may be associated with the presence of aromatic amino acids and volatile acids thathave a highly conjugated aliphatic structure, the intensity at $330 \mathrm{~nm}$ may be related to the presence of compounds such as naphthalene and derivatives, as well as the intensity at $400 \mathrm{~nm}$ is associated with the presence of aromatic polycyclic structures formed by about five conjugated rings [76, 77].

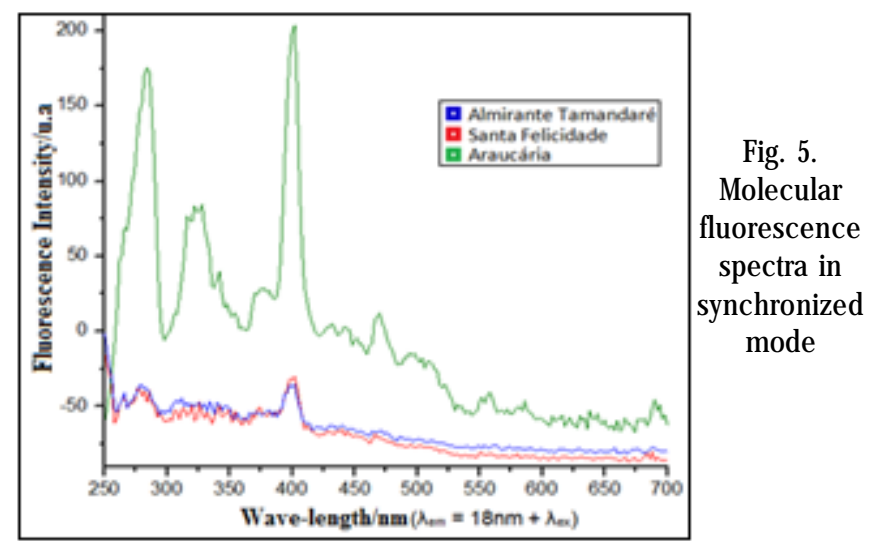

\begin{tabular}{|c|c|c|c|}
\hline & A & SF & AT \\
\hline $\mathbf{E}_{250} / \mathbf{E}_{203}$ & 0.35 & 0.06 & 0.07 \\
\hline $\mathbf{E}_{250} / \mathbf{E}_{365}$ & 3.9 & 1.6 & 1.6 \\
\hline $\mathbf{E}_{300} / \mathbf{E}_{400}$ & 3.9 & 2.0 & 1.9 \\
\hline $\mathbf{E}_{465} / \mathbf{E}_{665}$ & 0.3 & 4.0 & 3.2 \\
\hline
\end{tabular}

Table 3

ABSORBANCE RATIOS OF MOLECULAR ABSORPTION SPECTRA 


\begin{tabular}{|c|c|c|c|c|c|c|}
\hline & $\mathrm{Cu}$ & $\mathrm{Ni}$ & $\mathrm{Fe}$ & $\mathbf{C r}$ & $\mathrm{Zn}$ & $\mathbf{P b}$ \\
\hline $\operatorname{LDM}\left(\mathrm{mg} \mathrm{L}^{-1}\right)$ & 0.03 & 0.04 & 0.07 & 0.20 & 0.12 & 0.09 \\
\hline Precision (\%) & 0.60 & 0.80 & 1.80 & 3.50 & 2.20 & 1.70 \\
\hline Accuracy (\%) & 101.00 & 96.40 & 83.50 & 113.20 & 104.40 & 109.70 \\
\hline$A\left(\mathrm{mg} \mathrm{L}^{-1}\right)$ & $\mathrm{ND}^{1}$ & $\mathrm{ND}^{1}$ & $5.60 \pm 0.49$ & $\mathrm{ND}^{1}$ & $\mathrm{ND}^{1}$ & $1.40 \pm 0.16$ \\
\hline $\mathrm{SF}\left(\mathrm{mg} \mathrm{L}^{-1}\right)$ & $\mathrm{ND}^{1}$ & $\mathrm{ND}^{1}$ & $9.50 \pm 1.00$ & $\mathrm{ND}^{1}$ & $\mathrm{ND}^{1}$ & $1.10 \pm 0.10$ \\
\hline $\mathrm{AT}\left(\mathrm{mg} \mathrm{L}^{-1}\right)$ & $\mathrm{ND}^{1}$ & $\mathrm{ND}^{1}$ & $0.40 \pm 0.02$ & $0.72 \pm 0.03$ & $\mathrm{ND}^{1}$ & $0.45 \pm 0.05$ \\
\hline 357/CONAMA & NAVT $^{2}$ & 0.02 & NAVT $^{2}$ & 0.05 & 5.00 & 0.03 \\
\hline
\end{tabular}

*(A) Araucária; (SF) Santa Felicidade and (AT) Almirante Tamandaré

$\mathrm{ND}^{1}=$ Not detected

$\mathrm{NAVT}^{2}=$ Does not present total values under resolution 357 in 2005 of CONAMA

\section{Determination of metallic species}

Analyzes shows the average concentrations of the metal species in the total fraction, as well as the figures of analytical merit (table 4).

Lead concentrations at sample points are higher than the threshold defined by resolution 357 of 2005 [ 45]. These values can be associated to the species input, since in these regions there are industrial activities with the presence of materials casting, fertilizer production and pesticides, representing an important impact on the environment.

\section{Acute Environmental Toxicity Testing}

In the acute toxicity tests with the organism Arthemia $s p$., the negative control was performed in artificial marine water, in the presence of ten organisms and presented survival of $100 \%$ of the organisms. The positive control was done with the reference substance sodium dodecyl sulfate (SDS), in different concentrations, in the presence of ten organisms. All assays were performed in triplicate (fig. 6).

According to the validity criteria of the N-2588 standard (Petrobras, 1996), the test result was accepted because there was no evidence of mortality above $10 \%$ in the negative control of the test organisms. For the positive control, the LC50 value of the toxic reference substance (SDS) in the first 24 hwas in the concentration range between 13.9 and $30.9 \mathrm{mg} \mathrm{L}^{-1}$.

The acute toxicity tests with the microcrystalline Artemia sp., resulted in low rates of immobility of the

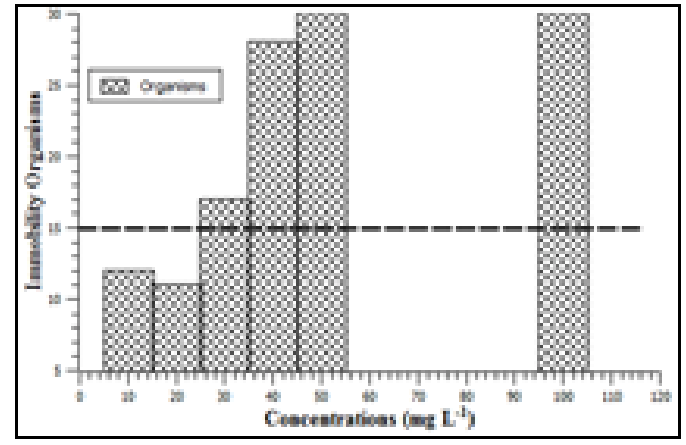

Fig. 6. Acute toxicity with reference substance - SDS / 24h organisms at all concentrations investigated, not allowing the establishment of the LC 50 in both 24 and $48 \mathrm{~h}$ (fig. 7). These results suggest the absence of a toxic effect on the organism Artemia sp. In order to perform the acute toxicity tests with the organism Daphnia magna, they were processed following the criterion of inhibiting the swimming capacity of organisms in static systems with temperature control and BOD greenhouse luminance according to methodologies proposed by Knie \& Lopes [42].

Preliminary tests were initially carried out with 10 organisms and counted after $48 \mathrm{~h}$ of assay to evaluate the range of organism responses in relation to the dilution criteria of the samples (table 5).

In samples of unknown toxic potential, such as natural water samples, this procedure is recommended to

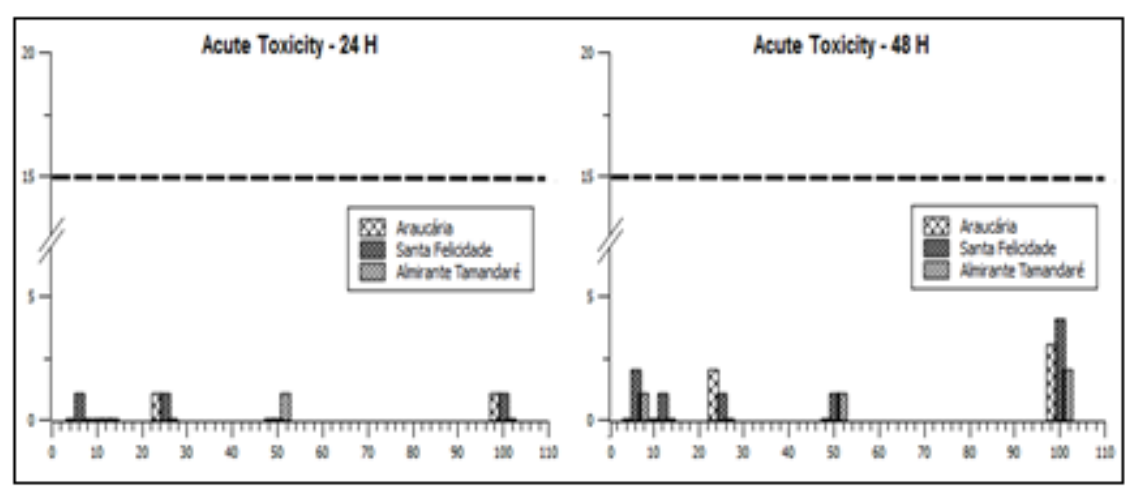

Fig. 7. Acute toxicity Artemia sp. evaluations in 24 and $48 \mathrm{~h}$, Barigui river

\begin{tabular}{|c|c|c|c|c|c|c|c|c|c|}
\hline \multicolumn{4}{|c|}{ SANTA FELICIDADE } & \multicolumn{5}{c|}{ ARAUCÁRIA } \\
\hline \multicolumn{3}{|c|}{ Preliminary Test - 10 organiams/48H } & \multicolumn{4}{c|}{ Preliminary Test - 10 organisms/48H } \\
\hline Diluition & \multicolumn{3}{|c|}{ Imobilized Organisms } & Average & Dilution & \multicolumn{2}{|c|}{ Imobilized Organisms } & Average \\
\hline $\mathbf{1}$ & 0 & 0 & 0 & 0,0 & $\mathbf{1}$ & 0 & 0 & 0 & 0,0 \\
\hline $\mathbf{2}$ & 3 & 2 & 4 & 3.0 & $\mathbf{2}$ & 0 & 0 & 0 & 0.0 \\
\hline $\mathbf{4}$ & 0 & $\mathbf{1}$ & 0 & 0.3 & $\mathbf{4}$ & 0 & 0 & 0 & 0.0 \\
\hline $\mathbf{8}$ & 0 & 0 & 0 & 0.0 & $\mathbf{8}$ & 0 & 0 & 0 & 0.0 \\
\hline Control & 0 & 0 & 0 & 0 & Control & 0 & 0 & 0 & 0 \\
\hline
\end{tabular}

Table 5

PRELIMINARY ESSAY WITH ORGANISM DAPHNIAMAGNA 


\begin{tabular}{|c|c|c|c|c|c|c|c|c|c|}
\hline \multicolumn{4}{|c|}{ SANTA FELICIDADE } & \multicolumn{5}{c|}{ ARAUCÁRIA } \\
\hline \multicolumn{3}{|c|}{ Definitive Test - 20 organigms/48H } & \multicolumn{4}{c|}{ Definitive Test - 20 organiams/48H } \\
\hline Diluition & \multicolumn{2}{|c|}{ Imobilized Organisms } & Average & Dilution & \multicolumn{2}{|c|}{ Imobilized Organisms } & Average \\
\hline $\mathbf{1 0 0} \%$ & 2 & 1 & 0 & 1 & $\mathbf{1 0 0} \%$ & 0 & 0 & 0 & 0 \\
\hline $\mathbf{7 5} \%$ & 0 & 0 & 0 & 0 & $\mathbf{7 5} \%$ & 0 & 0 & 0 & 0 \\
\hline $\mathbf{5 0} \%$ & 0 & 0 & 0 & 0 & $\mathbf{5 0} \%$ & 0 & 0 & 0 & 0 \\
\hline $\mathbf{2 5} \%$ & 0 & 0 & 0 & 0 & $\mathbf{2 5} \%$ & 0 & 0 & 0 & 0 \\
\hline $\mathbf{1 0} \%$ & 0 & 0 & 0 & 0 & $\mathbf{1 0} \%$ & 0 & 0 & 0 & 0 \\
\hline Control & 0 & 0 & 0 & 0 & Control & 0 & 0 & 0 & 0 \\
\hline
\end{tabular}

Table 6

DEFINITIVE ESSAY WITH ORGANISM DAPHNIAMAGNA establish the range that causes immobility in $100 \%$ of organisms and dilution in which an effect less than $10 \%$ is observed [42]. From the results (table 6), $50 \mathrm{~mL}$ aliquots were defined as dilutions for the final assay at concentrations of $100,75,50,25$ and $10 \%$.

The results point to the lack of LC 50 in the preliminary and definitive tests, so the sample did not present toxicity to the test organism Daphnia magna. These results are similar to those established in the tests carried out with the organism Artemia sp., and reinforce the need for more in-depth studies with the use of other test organisms of different trophic levels for the monitoring of toxicity at the sampling points.

\section{Conclusions}

The distinct behavior of the waters of the Barigui River, mainly in its portion of greater industrialization, allows to classify the sampling point of Araucária (A) as a reducing environment, with a higher contribution of dissolved solids, with low concentrations of dissolved oxygen that is probably being consumed in the degradation of the organic matter input in the region, when compared to the points of Almirante Tamandare and Santa Felicidade. These results in the Araucária region are associated with higher Alkalinity, Ammonia and Total Phosphorus concentrations when compared to the values of the other sampling areas and may be related to processes that influence the primary productivity, organic matter decomposition, respiration rate of microorganisms, release and dissolution of $\mathrm{CO}_{2}$ in water.

Also, we can classify the environment in Araucaria as Supertrophic presenting differentiation in relation to the presence of humic substances of the other regions. In addition, we can highlight the presence of metallic species in concentrations higher than those recommended by resolution 357 of 2005 [45].

Although environmental degradation was chemically characterized in the Barigüi River regions, there was no evidence of biological responses in the acute toxicity trials. This suggests the need for further investigations on the environmental toxicity of the water system as well as the use of different lines of study in order to characterize the environmental risk assessment.

The Barigui River is part of the landscape of the metropolitan region of Curitiba in the state of Parana, southern Brazil, being an important tributary of the Iguaçu River Basin, considered to be the largest Parana system with a total of $1320 \mathrm{~km}$ and about $70.800 \mathrm{~km}^{2}$ [49]. At the mouth of the river Barigui, where it joins Iguacu River the average long-term flow of the Barigui River is $4.8 \mathrm{~m}^{3} / \mathrm{s}$ and its minimum long-term flow is $1.4 \mathrm{~m}^{3} / \mathrm{s}$. Its waters are monitored by the Environmental Institute of Parana (IAP) and present classifications ranging from polluted to heavily polluted to the Integrated Water Quality Assessment method [50].

The environmental risk associated with the waters of the Barigüi River reflects in environmental problems not only in the metropolitan region of Curitiba, but in much of the south of the country due to its connection with the Iguaçu system. This fact has not been able to raise the attention for greater care by the regional governmental authorities.

Acknowledgments: The authors are grateful for the contributions made to the study by the geographer Adelson Raimundo Angelo and the technologist in environmental processes Thalita Copelli. We also thank the material and financial support of the Coordination for the Improvement of Higher Education Personnel; The Federal Ministry of Santa Maria (UFSM) and the Federal Technological University of Paraná (UTFPR).

\section{References}

1.WANG, Z., YAO, L., LIU, G., LIU, W., Heavy metals in water, sediments and submerged macrophytes in ponds around the Dianchi Lake, China. Ecotoxicology and Environmental Safety, 107, 2014, pp. 200206.

2.PHILIPPI, A., SILVEIRA, V.F., Controle da Qualidade das Águas. Saneamento, Saúde e Ambiente. Editora da USP. 2005.

3.BRICIU, A.E., TOADER, E., ROMANESCU, G., SANDU, I., Urban Streamwater Contamination and Self-purification in a Central-Eastern European City. Part I, Rev. Chim. (Bucharest), 67, no.7, 2016, p. 1294 4.BRICIU, A.E., TOADER, E., ROMANESCU, G., SANDU, I., Urban Streamwater Contamination and Self-purification in a Central-Eastern European City. Part B, Rev. Chim. (Bucharest), 67, no. 8, 2016, p. 1583 5.DIRTU, D., PANCU, M., MINEA, M.L., DIRTU, A.C., SANDU, I., Occurrence and Assessment of Selected Chemical Contaminants in Drinking Water from Eastern Romania, Rev. Chim. (Bucharest), 67, no. 10, 2016, p. 2059

6.ROMANESCU, G., MIFTODE, D., MIHU-PINTILIE, A., STOLERIU, C.C., SANDU, I., Water Quality Analysis in Mountain Freshwater: Poiana Uzului Reservoir in the Eastern Carpathians, Rev. Chim. (Bucharest), 67, no. 11, 2016, p. 2318

7.DIRTU, D., PANCU, M., MINEA, M.L., CHIRAZI, M., SANDU, I., DIRTU, A.C., Study of the Quality Indicators for the Indoor Swimming Pool Water Samples in Romania, Rev. Chim. (Bucharest), 67, no. 6, 2016, p. 1167

8.PAPADATU, C.P., BORDEI, M., ROMANESCU, G., SANDU, I., Researches on Heavy Metals Determination from Water and Soil in Galati County, Romania, Rev. Chim. (Bucharest), 67, no. 9, 2016, p. 1728

9.ROMANESCU, G., TARNOVAN, A., SANDU, I.G., COJOC, G.M., DASCALITA, D., SANDU, I., The Quality of Surface Waters in the Suha Hydrographic Basin (Oriental Carpathian Mountains), Rev. Chim. (Bucharest), 65, no. 10, 2014, p. 1168

10.ROMANESCU, G., PAUN, E., SANDU, I., JORA, I., PANAITESCU, E., MACHIDON, O., STOLERIU, C., Quantitative and Qualitative Assessments of Groundwater into the Catchment of Vaslui River, Rev. Chim. (Bucharest), 65, no. 4, 2014, p. 401

11.ROMANESCU, G., HAPCIUC, O.E., SANDU, I., MINEA, I., DASCALITA, D., IOSUB, M., Quality Indicators for Suceava River, Rev. Chim. (Bucharest), 67, no.2, 2016, p. 245

12.SALEM, Z.B., CAPELLI, N., LAFFRAY, X., ELISE, G., AYADI, H., ALEYA, $L$., Seasonal variation of heavy metals in water, sediment and 
roachtissues in a landfill draining system pond (Etueffont, France). Ecological Engineering, 69, 2014, pp. 25-37.

13.ESTEVES, F.A., GUARIENTO, R.D., Elementos-Traço. Fundamentos de Limnologia. Rio de Janeiro: Interciência, 2011.

14.ANCION, P.Y., LEAR, G., DOPHEIDE, A., LEWIS, G.D., Metal concentrations in stream biofilm and sediments and their potential to explain biofilm microbial community structure. Environmental Pollution, 173, 2013, pp. 117-123.

15.BURTON, G.A., Metal Bioavailability and toxicity in sediments. Environmental Science and Technology, 40, 2010, pp. 852-907.

16.ROMANESCU, G., ZAHARIA, C., SANDU, A.V., JURAVLE, D.T., The Annual And Multi-Annual Variation of the Minimum Discharge in the Miletin Catchment (Romania). an Important Issue of Water Conservation, International J ournal of Conservation Science 6, no. 4, 2015, pp. 729-746.

17.ROMANESCU, G., COJOC, G.M., SANDU, I.G., TIRNOVAN, A., DASCALITA, D., SANDU, I., Polution Sources and Water Quality in the Bistrita Catchment (Eastern Carpathians), Rev. Chim. (Bucharest), 67, no. 6, 2016, p. 855

18.SEDRATI A., HOUHA B., ROMANESCU G., SANDU I.G., DIACONU D.C., SANDU I., Impact of Agriculture Upon the Chemical Quality of Groundwaters within the Saharian Atlas Steppe El-Meita (KhenchelaAlgeria), Rev. Chim. (Bucharest), 68, no. 2, 2017, p. 420

19.VASILACHE, V., CRETU, M.A., PASCU, L.F., RISCA, M., CIORNEA, E., MAXIM, C., SANDU, I.G., CIOBANU, C.I., Dehydrogenases Activity In Sludge Samples of Suceava River, International J ournal of Conservation Science, 6, no. 1, 2015, pp. 93-98.

20.SANTOS, S., OLIVEIRA, L.C., SANTOS, A., ROCHA, J.C., ROSA, A.H.R., Poluição Aquatica. Meio Ambiente \& Sustentabilidade. Porto Alegre: Bookman, 2012, pp. 17-46.

21.ROMANESCU, G., COJOC, G.M., SANDU, I.G., TIRNOVAN, A., DASCALITA, D., SANDU, I., Pollution Sources and Water Quality in the Bistrita Catchment (Eastern Carpathians), Rev. Chim. (Bucharest), 66 no. 6, 2015, pp. 855-863.

22.GERBERSDORF, S.U., HOLLERT, H., BRINKMANN, M., WIEPRECH, S., SCHÜTTRUMPF, H., MANZ, W., Anthropogenic pollutants affect ecosystem services of freshwater sediments: the need for a triad plus $x$ approach., J ournal of the Soils and Sediment, 11, 2011, pp.10991114.

23.ROMANESCU, G., SANDU, I., STOLERIU, C., SANDU, I.G., Water Resources in Romania and Their Quality in the Main Lacustrine Basins, Rev. Chim. (Bucharest), 65, no. 3, 2014, p. 344

24.MARUSIC, G.,; SANDU, I., VASILACHE, V., FILOTE, C., SEVCENCO, N., CRETU, M.A., Modeling of Spacio-temporal Evolution of Fluoride Dispersion in River-type Systems, Rev. Chim. (Bucharest), 66, no. 4, 2015, p. 503

25.ROMANESCU, G., IOSUB, M., SANDU, I., MINEA, I., ENEA, A., DASCALITA, D., HAPCIUC, O.E., Spatio-temporal Analysis of the Water Quality of the Ozana River, Rev. Chim. (Bucharest), 67, no. 1, 2016, p. 42

26.VASILACHE, V., FILOTE, C., CRETU, M.A., SANDU, I., COISIN, V., VASILACHE, T ., MAXIM, C., Monitoring of Groundwater Quality in Some Vulnerable Areas in Botosani County for Nitrates and Nitrites Based Pollutants, Environmental Engineering And Management Journal, 11, no. 2, 2012, pp. 471-479.

27.ROMANESCU, G., PASCAL, M., MIHU-PINTILIE, A., STOLERIU, C.C., SANDU, I., MOISII, M., Water Quality Analysis in Wetlands Freshwater: Common Floodplain of Jijia-Prut Rivers, Rev. Chim. (Bucharest), 68 no. 3, 2017, p. 553

28.ROMANESCU, G., TIRNOVAN, A., COJOC, G.M., JURAVLE, D.T., SANDU, I., Groundwater Quality in Suha Basin (Northern Group of Eastern Carpathians), Rev. Chim. (Bucharest), 66 no. 11, 2015, p. 1885

29.ESTEVES, F.A., AMADO, A. M., Nitrogênio. in: Fundamentos de Limnologia. Rio e J aneiro/BRA: Editora Interciência, 2011.

30.MELO, V.F., ANDRADE, M., BATISTA, A.H., FAVARETTO, N., GRASSI, M.T., CAMPOS; M.S., Chumbo e zinco em Águas e Sedimentos de Área de Mineração e Metalurgia de Metais. Química Nova, 35, no. 1, 2012, pp. 22-29.

REV.CHIM. (Bucharest) $68 \diamond$ No. $8 \diamond 2017$

http://www.revistadechimie.ro
31.SIQUEIRA, G.W., APRILE, F., Avaliação de risco ambiental por contaminação metálica e material orgânico em sedimentos da bacia do Rio Aurá, Região Metropolitana de Belém - PA. Acta Amazonica, 43, no. 1, 2013, pp. 51-62.

32.BURTON, G.A.; JOHNSTON, E., Avaliação de sedimentos contaminados no contexto de Múltiplos Estressores. Environmental Toxicology and Chemistry, 29, no. 12, 2010, p. 2625-2646.

33.*** USEPA - U.S. Environmental Protection Agency; NOAA - National Oceanic and Atmospheric Administration; EVS - Environment Consultants. Sheboygan River and Harbor: aquatic ecological risk assessment. Chicago: United States of America, 1998.

34.NURUZZAMAN, M., AL-MAMUN, A., BIN SALLEH, M.N., Challenges in the Rehabilitation of the Pusu River, International Journal of Conservation Science, 8, no. 1, 2017, p. 121

35.ROMANESCU, G., CRETU, M.A., SANDU, I.G., PAUN, E., SANDU, I., Chemism of Streams Within the Siret and Prut Drainage Basins: Water Resources and Management, Rev. Chim. (Bucharest), 64, no. 12, 2013, p. 1416

36.ROMANESCU, G., TIRNOVAN, A., SANDU, I., COJ OC, G.M., BREABAN, I.G., MIHU-PINTILIE, A., Water Chemism Within the Settling Pond of Valea Straja and the Quality of the Suha Water Body (Eastern Carpathians), Rev. Chim. (Bucharest), 66, no. 10, 2015, p. 1700 37.BEJ INARIU, C., SANDU, A.V., BACIU, C., SANDU, I., TOMA, S.L., SANDU, I.G., Water Treatment and Detoxification of the By-products Resulted from Lubricating Phosphatation of Iron-Based Metal Parts, Rev. Chim. (Bucharest), 61 no. 10, 2010, p. 961

38.ROMANESCU, G., TIRNOVAN, A., COJOC, G.M., SANDU, I.G., Temporal Variability of Minimum Liquid Discharge in Suha Basin. Secure Water Resources and Preservation Possibilities, International Journal of Conservation Science, 7, no. 4, 2016, pp. 1135-1144.

39.SAHU, P.C., Groundwater Resource Conservation and Augmentation in Hard Rock Terrain: An Integrated Geological and Geo-Spatial Approach, International Journal of Conservation Science, 8, no. 1, 2017, pp. 145-156.

40.MONTANO, M.; SOUZA, M.P. Avaliacao ambiental no licenciamento de empreendimentos perigosos no estado de São Paulo. Revista Engenharia Sanitária e Ambiental. 13, no. 4, 2008, pp. 435-442.

41.ARAGÃO, M.A., ARAÚJ O, P.A., Métodos de Ensaio de Toxicidade com Organismos Aquáticos. In: Ecotoxicologia Aquática: princípios e aplicações. Sao Carlos: Rima, 2008.

42.KNIE, J.L.W., LOPES, E.W.B., Testes Ecotoxicológicos: Métodos, Técnicas e Aplicações. Florianópolis: FATMA, 2004.

43.RADULESCU, C., POHOATA, A., BRETCAN, P., TANISLAV, D., STIHI, C., CHELARESCU, E., Quantification of major ions in groundwaters using analytical techniques and statistical approaches, Romanian Reports in Physics, 69, no. 2, 2017, Article Number: 705.

44.CHELARESCU, E.D., RADULESCU, C., STIHI, C., BRETCAN, P., TANISLAV, D., DULAMA, I.D., STIRBESCU, R.M., TEODORESCU, S., BUCURICA, I.A., ANDREI, R., MORARESCU, C., Analysis of elements in lake sediment samples by PIXE spectrometry. Nuclear Instruments and Methods in Physics Research, Section B: Beam Interactions with Materials and Atoms, 406, Part A, 2017, pp. 58-60. 45.CONAMA - Conselho Nacional do Meio Ambiente. Resoluções do Conama: Resoluções vigentes publicadas entre setembro de 1984 e janeiro de 2012. Brásilia: Ministério do Meio Ambiente, 2012.

46.*** APHA - American Public Health Association. Standard Methods for the Examination of Water and Wastewater. Washington, 2005. 47.*** CETESB - Companhia Ambiental do Estado de São Paulo. Norma Técnica L5.306. Determinação de Clorofila a e Feofitina a: método espectrofotométrico. São Paulo: Governo do Estado de São Paulo, 14, 2014.

48.MACHADO, K. S.; FIGUEIRA, R. C. L.; CÔCCO, L. C.; FROEHNER, S.; FERNANDES, C. V. S; FERREIRA, P. A. L. Sedimentary record of $\mathrm{PAHs}$ in the Barigui River and its relation to the socioeconomic development of Curitiba, Brazil. Science of the Total Environment, 2014.

49.SEMA. Bacias Hidrográficas do Paraná: série histórica. Secretária de Meio Ambiente e Recursos Hídricos. Governo do Estado do Paraná, 2013. 
50.*** IAP - Instituto Ambiental do Paraná. Monitoramento da Qualidade das Águas dos Rios da Bacia do Alto Iguaçu na Regiao Metropolitana de Curitiba no período de 2005. Secretária do Meio Ambiente do Estado do Paraná, 2009.

51.FROEHNER, S.; MARTINS, R. F. Avaliação da Composição Química de Sedimentos do Rio Barigüi na Região Metropolitana de Curitiba. Quimica Nova, 2008.

52.ANA/CETESB. Guia Nacional de Coleta e Preservação de Amostras: água, sedimento, comunidades aquáticas e efluentes líquidos. São Paulo: Governo do Estado de São Paulo, 2011.

53.PARRON, L.M.; MUNIS,D.H.F.; PEREIRA, C.M. Amostragens para Análise Físico-Quimica. Manual de Procedimentos de Amostragem e Análise Físico-Química de Agua. Colombo: Embrapa Florestas. 2011 54.USEPA, Method 1669. Sampling Ambient Water for Trace Metals at EPA Water Quality Criteria Levels. Washington DC, 1996.

55.SILVA, P.R.B. Avaliação de qualidade das águas e sedimentos da sub-bacia do rio Barigüi, região metropolitana de Curitiba - PR. (Dissertação). Programa de Pós-Graduação em Ciência e Tecnologia Ambiental da Universidade Tecnológica Federal do Paraná, 2015. 56.RADULESCU, C., STIHI, C., DULAMA, I.D., CHELARESCU, E.D. BRETCAN, P., TANISLAV, D., Assessment of heavy metals content in water and mud of several salt lakes from Romania by atomic absorption spectrometry, Romanian J. Phys. 60, no. 1-2, 2015, p. 246256.

57.*** USEPA, 200.2. Sample Preparation Procedure for Spectrochemical Determination of Total Recoverable Elements. United States Environmental Protection Agency, Washington, DC, 1994. 58.*** INMETRO - Instituto Nacional de Metrologia, Qualidade e Tecnologia. Orientação sobre Validação de Métodos Analíticos. São Paulo: Coordenação Geral de Acreditação, 2011.

59.*** ANVISA - Agencia Nacional de Vigilância Sanitária. Guia para Validação de Métodos Analíticos e Bioanaliticos. Brasília, DF, 2003. 60 .**8 USEPA, 821 R-02-012. Methods for measuring the acute toxicity of effluents and receiving Waters to freshw ater and marine organisms. United States Environmental Protection Agency, Washington, DC, 2002. 61.PIMENTEL, M.F., SILVA JUNIOR, F.C.G., SANTAELLA, S.T., LOTUFO, L.V.C.O., Uso de Artemia sp. como Organismo-Teste para Avaliação da Toxicidade das Águas Residuárias do Beneficiamento da Castanha de Caju Antes e Após Tratamento em Reator Biológico Experimental. Journal Brazilian Society Ecotoxicology, 2011.

62.VEIGA, L.F., VITAL, N. Testes de Toxicidade Aguda com o Microcrustáceo Artemia sp. Métodos em Ecotoxicologia Marinha, 2002. 63.DOMINGUES, D.F. BERTOLETTI, E. Seleção, Manutenção e Cultivo de Organismos Aquáticos. In: Ecotoxicologia Aquática: princípios e aplicações. São Carlos: Rima, 2008.

64.ARAGÃO, M.A., ARAÚj O, P.A. Métodos de Ensaio de Toxicidade com Organismos Aquáticos. Ecotoxicologia Aquática: Princípios e Aplicações. São Carlos: Editora Rima, 2008.
65.ROCHA, J.C., ROSA, A.H., CARDOSO, A.A., Recursos Hídricos. Introdução a Química Ambiental. Porto Alegre: Bookman, 2009. 66.GUIMARÃES, I.R., MANIERO, M.G., Tratamento de Água e Efluentes Líquidos. Meio Ambiente \& Sustentabilidade. Porto Alegre: Bookman, 2012.

67.CAMPOS, M.L.A.M., Introdução a Biogeoquímica de Ambientes Aquáticos. Campinas: Átomo, 2010.

68.GONÇALVES, Mariane. Furtado. Variação Temporal e Espacial da Presença dos Metais Pesados $\mathrm{Cd}, \mathrm{Cr}, \mathrm{Ni}, \mathrm{Zn}$ e Pb na Bacia do Rio Barigüi e Identificação de sua Fontes Potenciais. (Dissertação) Programa de Pós-Graduação em Engenharia de Recursos Hídricos e Ambiental da Universidade Federal do Paraná, 2008.

69.CARVALHO. Maiara. Soares de. Análise Nictimeral de Rios Urbanos: Estudo de Caso no Rio Barigüi - Curitiba - PR. Anais do XX Simpósio Brasileiro de Recursos Hídricos, 2013.

70.SCHEFFER, E.W., SODRÉ, F.F., GRASSI, M.T., Fatores que governam a especiação de Cobre em Ambientes Aquáticos Urbanos: Evidências da Contribuição de Sulfetos Soluveis, Química Nova, 30, no. 2, 2007, http://dx.doi.org/10.1590/S0100-40422007000200018

71.FRITZSONS, E., MANTOVANI, L.E., NETO, A.C., HINDI, E.C., A influência das atividades mineradoras na alteracao do $\mathrm{pH}$ e da alcalinidade em águas fluviais: o exemplo do rio Capivari, região do carste paranaense, Engenharia Sanitária e Ambiental, 14, no. 3, 2009, pp.381-390.

72.FAGNANI, E.; GUIMARÃES, J.R.; MOZETO, A.A.; FADINI, P.S. Sulfetos Volatizáveis por Acidificacao e Metais Extraídos Simultaneamente na Avaliação de Sedimentos de Água Docê. Química Nova, 34, no. 9, 2011, pp. 1618-1628.

73.BOTERO, W.G., SOUZA, S.O., SANTOS, O.S., OLIVEIRA, L.C., AMARANTE, C.B., A influência das substâncias húmicas de sedimentos na biodisponibilidade de metais para o sistema aquático, Quimica Nova, 37, no. 6, 2014, pp. 943-949.

74.CHEN, J., GU, B., LEBOEUF, E.J., PAN, H., DAÍ, S., Spectroscopic characterization of the structural and functional properties of natural organic matter fractions. In: Chemosphere, 2002.

75.AZEVEDO, J.C.R., NOZAKI, J., Análise de Fluorescência de Substâncias Húmicas Extraidas da Água, Solo e Sedimento da Lagoa dos Patos - MS, Química Nova, 31, no. 6, 2008, pp. 1324-1329.

76.ROCHA, J.C., ROSA, A.H., Substâncias húmicas aquáticas: interação com espécies metálicas. Editora Unesp, Sao Paulo, 2003.

77.CAO, J., LAM, K.C., DAWSON, R.W., LIU, W.X., TAO, S., The effect of $\mathrm{pH}$, ion strength and reactant content on the complexation of $\mathrm{Cu}^{2+}$ by various natural organic ligands from water and soil in Hong Kong, Chemosphere, 54, 2004, pp.507-514.

Manuscript received: 21.02.2017 